\title{
Green Worship House Competition as an Effective Tool to Evaluate Green Pyramid Rating System (GPRS)
}

\author{
Nancy M. Badawy ${ }^{1} \&$ Merhan M. Shahda ${ }^{1}$ \\ ${ }^{1}$ Architecture and Urban Planning Department, Faculty of Engineering, Port-Said University, Port Said, Egypt \\ Correspondence: Merhan M. Shahda, Architecture and Urban Planning Department, Faculty of Engineering, \\ Port-Said University, Port Said 42526, Egypt. Tel: 2-066-344-6100. E-mail: m.shahda@eng.psu.edu.eg
}

Received: November 19, 2019

Accepted: December 6, 2019 Online Published: December 30, 2019

doi:10.5539/jsd.v13n1p18

URL: https://doi.org/10.5539/jsd.v13n1p18

\begin{abstract}
Egypt is divided into seven regional units; each region includes a number of governorates that are connected geographically and economically. When the Green Pyramid Rating System (GPRS) was proposed, and the weightings of its categories were set, the wide variation of the potential and the challenges of each region were not taken into account. Therefore, the study focused on highlighting these differences, and the main focus on Sinai region by analyzing the experience of activating The Green Pyramid Rating System (GPRS) during a competition held for this purpose. Accordingly, this paper presents an investigation into the international GBRSs to extract the specifications of a framework to improve GPRS classification, based on the experience of activating GPRS principles in Green Worship House Competition (GWHC) and the observations of participants of the competition. The study included a summary of what was suggested during participation in the competition to activate each category of Green Pyramid Rating System (GPRS), in addition to observations and problems encountered in the design of the project and activation of (GPRS) categories, then suggestions for developing the categories and weights of each category based on active participation in the Green Worship House Competition.
\end{abstract}

Keywords: Green Pyramid Rating System, architecture competition, rating system implementation, certification systems, Sinai

\section{Introduction}

Since 1982, various tools for building environmental assessment have begun to appear all over the world (Wenzel et al., 2000; Todd et al., 2000). Most countries have been trying to launch their own rating systems to encourage the sustainable process assessment; each one has its own goals, needs, and way of use. All these rating systems are built in to adapt sustainability concept in architecture which seeks to minimize the negative environmental impact of buildings to promote high-performance buildings by conscious use of water, materials, energy, and space. These assessment tools differ in their concepts of including life cycle cost and assessment, energy performance, indoor environmental quality assessments, operations and maintenance optimization, whole building design and operations tools, and more (Elmeligy, 2014; Attia et al., 2013; Ali \& Al Nsairat, 2009; Reich, 2005; Gowri, 2004).The need for green building assessment tool has increased in developing countries because of the environment, as it is a generally accepted fact that in order to manage anything there is a need to be able to measure it. This fact underlines the urgent need for a national system for rating the green credentials of buildings in Egypt which is suitable for the surrounding environment. The Green Pyramid Rating System (GPRS) has been developed to meet this need (Green Pyramid Rating System (GPRS), 2011). It has been developed by the USA LEED. In January 2009, the Egyptian Council was established for evaluating green building, then the Board issued a primary version of the Egyptian pyramid in 2010 (Aleem et al., 2015; Attia, 2014; Council, 2009). The Green Pyramid Rating System (GPRS) was not applied or experienced very well at that time. Moreover, it was not addressing local problems or conditions such as mismanagement and lack of awareness and training.

According to (Zannoun, 2009), GPRS has been developed by the global system (LEED) in spite of the difference in the economic, technological and social and cultural aspects between the two countries, and the fact that it was not addressing local problems such as mismanagement and lack of awareness and training, it has been created by a governmental body, with the absence of any support from other segments of the society. As (GWHC) competition comes as a pilot initiative for expanding the application of (GPRS) in other building types and scales, 
and so as to investigate the assessment criteria stated by the Green Pyramids rating system and to apply it in their design, the paper aims to make the best use of the competition to improve the GPRS.

The GPRS needs to be tested, spread, put up for social discussion and there is a need to take steps to raise national awareness about it, therefore a national competition is a powerful tool for this. Design competitions can link the academic side with practical application (Guilherme \& Salema, 2017). Accordingly, this paper describes the Green Worship House Competition (GWHC) as well as one of the experiences of participation that has been designed according to GPRS. This competition can contribute to the development of the Egyptian Pyramid to promote the development of better future implementation in Egypt. Design competitions are regarded as an architectural policy tool for renewal and quality development. It is also used as a foundation and an opportunity for testing important researches to provide the implementation of laboratory view with the community culture from different parties involved; promoters and architects, the public in order to improve the quality of the tested tool, which contribute to improving the whole rating system. Moreover, it helps in the understanding of design process, sustainability awareness and participation as a social discussion (da Costa, 2017; Menteth, 2017).

There are three roles that should be considered to reach better building environmental performance domain in the way of building tool assessmentsuchas (Cam \& Ong, 2005). There are as follows:

- The first role is to raise the awareness of different building environmental players in the design and construction sectors to reach a sustainable design. The Green Worship House Competition (GWHC) in Egypt was a step in this way to enhance the use of GPRS in design.

- The second role is to set benchmarks for building to activate the environmental practice, to safeguard the minimum performance standards, andforevaluating architectural design against these benchmarks. These benchmarks must be modified and evaluated by designers and society after that, and this what the paper focusses on.

- Finally providing a platform for inspiring new designs, ideas and technical solutions then the research crisis. The framework is based on the experience of the (GWHC) participation.

Each assessment rating system must be developed by all concerned stakeholders. This research applies the participation experience (GWHC) on crisis GPRS to reach the aimed specification of the developed framework.

\section{Materials and Methods}

This paper analyses different frameworks strategies of different building rating systems. Three strategies of classification have been used for the analysis. This paper presents an insight into the international GBRSs to extract the specifications of a framework to improve GPRS classification based on the experience of implementation of GPRS principles in (GWHC) participation. Finally, a criticism of the score weighting of the GPRS in competition participation case study is presented.

The constructed methodology to achieve research objectives consists of four steps:

- Broad-scale investigation of different frameworks of GBRSs.

- Macro-scale investigation of four GBRSs with four frameworks (LEED, CASBEE, BREEAM, ISB tool) and then comparison between them and the GPRS is held.

- Micro-scale investigation focuses on the GPRS system, which focuses on the apparent contrast between different regions in Egypt and the extent of variability in potentials and resources, that makes it difficult to apply fixed standards to all regions of Egypt.

- Proposed GPRS framework classification is based on the observations of participants in the competition about the problems encountered during the application of the criteria of the Green Pyramid Rating System in different regions.

\section{Strategies of Implementation and Applicability of (GBRSs)}

Different Green Building Rating and Certification systems (GBRSs) provide a systematic, holistic and practical approach of evaluation (Bendewald \& Zhai, 2013; Mateus \& Bragança, 2011). Most developing countries made several GBRSs according to different environmental, social and economic conditions which differ in their goals, needs, and mechanism even in each city. GBRSs have been critically compared in a number of studies according to many approaches:1) Their benefits and their role as decision aids; 2) Comprehensiveness, effectiveness and accuracy of assessment criteria; 3) Their related geographical references; 4) Their adoption rate; 5) Future development scenarios, challenges and new research directions (Ismaeel, 2019; Mattoni, 2018; Doan et al., 2017; Chen et al., 2015; Bauer et al., 2009; Haapio \& Viitaniemi, 2008). Every rating system is based on a 
comprehensive framework which is established according to different strategies. (see fig. 1.)

First strategy based on assessment methodology which is divided into two methodologies as (Ali \& Al Nsairat, 2009) and an added methodology which is SB method and SB tool. Hikmat explains the criteria system based on assigning point values to a selected number of parameters weighted according to social, economic, environmental, cultural and political impacts. This methodology is adapted by most assessment rating systems: 1) BREAM (Great Britain); 2) GB Tool (Canada) - IISBE, 3) LEED (US)-USGBC; 4) Eco-Profile (Norway), 5) GPRS(Egypt). Another methodology is Life Cycle Assessment (LCA) Methodology. Life Cycle Analysis is a tool for measuring the environmental performance of a building. It is also a technique to assess environmental impacts associated with all the stages of a building's life from raw material extraction through the construction process, occupancy of the building, maintenance, and disposal or recycling. All costs of acquiring, owning, and disposal of a building system is taken into account by Life cycle analysis. Decision-makers whether designers, executives or politicians use Life Cycle Analysis process to help critique their project alternatives (Ding, 2014; Khasreen et al., 2009; Haapio \& Viitaniemi, 2008). Examples of GBRSs are based on LCA are Bees (USA)-OAE, Beat (Denmark)-DBRI; Eco Quantum (Netherlands) (Malmqvist, 2005).Third methodology is adapted by another assessment rating system which is Integrated Design Process (IDP)used by regional third-party organizations to set locally relevant weights, benchmarks and standards established according to the potential functions (applicable areas) of the tools.

Table 1. Assessment methodology of (GBRSs)

\begin{tabular}{|c|c|c|c|}
\hline \multicolumn{4}{|c|}{ Assessment methodology } \\
\hline Types & Criteria System & $\begin{array}{l}\text { Life Cycle Assessment } \\
\text { (LCA) }\end{array}$ & $\begin{array}{l}\text { Integrated } \\
\text { Process (IDP) }\end{array}$ \\
\hline Description & $\begin{array}{l}\text { Numerically through a } \\
\text { design checklist of } \\
\text { mandatory prerequisites and } \\
\text { optional credits }\end{array}$ & $\begin{array}{l}\text { Takes into account all } \\
\text { costs of acquiring, } \\
\text { owning, and disposing of } \\
\text { a building system }\end{array}$ & $\begin{array}{l}\text { Benchmarks } \\
\text { standards established } \\
\text { according to third-party } \\
\text { locale relevant weights }\end{array}$ \\
\hline Implementation & $\begin{array}{l}\text { BREAM, GB Tool (Canada) } \\
\text { - IISBE } \\
\text { LEED (US)-USGBC } \\
\text { Eco-Profile (Norway) } \\
\text { GPRS(Egypt) }\end{array}$ & $\begin{array}{l}\text { Bees (USA)-OAE } \\
\text {, Beat (Denmark)-DBRI; } \\
\text { Ecorantum } \\
\text { (Netherlands) Quantum }\end{array}$ & ISB tool \\
\hline
\end{tabular}

Source: the author

Second strategy of classification is according to the potential functions (D-Tool) tools within the stakeholder and building activity category that are designed primarily to optimize, select, check, predict and evaluate decisions in the design stage (P-Tool) tools within the performance category that are designed for performance comparison and rating. They include issues which describe the targets of building activities (Ali \& Al Nsairat, 2009; Liu, 2005).

Third strategy of classification is that according to spatial adaptation, there are GBRSs resilient to different cities such as Comprehensive Assessment System for Built Environment Efficiency (CASBEE)-City (worldwide use version), which is specifically designed for city-scale assessment and can be applied to various types of cities globally (Murakami et al., 2011; 2010). As well as (ISP tool), it can be used in calibration to suit a large number of specific project types in different regions, and therefore weights and benchmarks must have broad validity. On the other hand, some other assessment methods are linked to absolute areas they are designed to. 


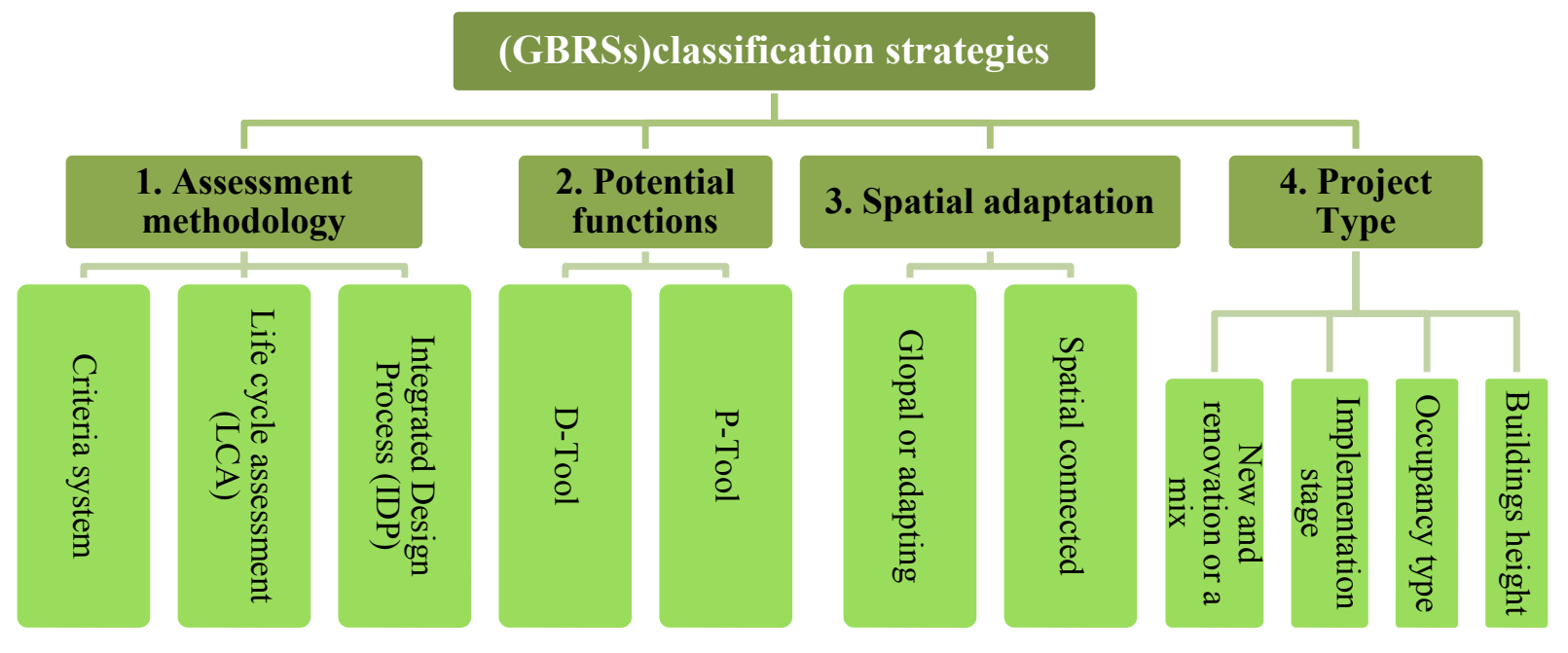

Figure 1. GPRSs classification strategies

Source: the author, Adapted from Refs. [33-42].

Fourth strategy is the type of project; it contains different categories as listed.

- New and renovation projects or a mix.

- Implementation stage (pre-design, design, construction, operations and maintenance).

- Occupancy type.

- Buildings height and system level (building, urban development, city....)

LEED is a very flexible tool that can be applied to all building types (Kubba, 2009). It works throughout the building lifecycle, from the design and construction stages through the operations and maintenance stages, until retrofit, taking into consideration not only the building footprint, but also the whole neighborhood (Holmes, S. 2018).

Each of BREEAM schemes are designed to assess the environmental performance of buildings at various stages in the life cycle (BREEAM, 2014; 2018) including:

- BREEAM Communities for the master-planning of a larger community of buildings.

- BREEAM New Construction for newly built, domestic and non-domestic buildings.

- BREEAM In-Use for existing non-domestic buildings in-use.

- BREEAM Refurbishment for domestic and, from summer 2014, non-domestic building fit-outs and refurbishments.

On the other hand, CASBEE is a system designed for spatial scale, such as individual buildings, urban districts and cities, as well as SB method, the system covers a wide range of sustainable building issues, not just green building concerns, but the scope of the system can be modified to be as narrow or as broad as desired, ranging from 100+ criteria to half a dozen (Rana \& Bhatt, 2016). While GPRS can be used to assess individual new buildings at either or both of the design stage and/or the post-construction stage, the documents of The Green Pyramid Rating System for new buildings at post-occupancy stage and The Green Pyramid Rating System for existing buildings have not yet been released (Ayyad \& Gabr, 2012), (see Table 2.). 
Table 2. Comparison between GBRSs on classification of strategies

\begin{tabular}{|c|c|c|c|c|c|c|c|c|c|c|c|}
\hline \multicolumn{12}{|c|}{ Comparison between GBRSs on classification of strategies } \\
\hline & \multicolumn{3}{|c|}{ 1. Assessment methodology } & \multicolumn{2}{|c|}{$\begin{array}{l}\text { 2.Potential } \\
\text { functions }\end{array}$} & \multicolumn{2}{|c|}{ 3. Spatial adaptation } & \multicolumn{4}{|c|}{ 4. Project Type } \\
\hline $\begin{array}{c}\text { Classification } \\
\text { strategies }\end{array}$ & $\begin{array}{l}\text { Criteria } \\
\text { system }\end{array}$ & $\begin{array}{c}\text { Life cycle } \\
\text { assessment } \\
\text { (LCA) }\end{array}$ & $\begin{array}{c}\text { Integrated } \\
\text { Design } \\
\text { Process } \\
\text { (IDP) }\end{array}$ & D-Tool & P-Tool & $\begin{array}{l}\text { Global or } \\
\text { adapting }\end{array}$ & $\begin{array}{c}\text { Spatial } \\
\text { connected }\end{array}$ & $\begin{array}{l}\text { New and } \\
\text { renovation } \\
\text { or a mix }\end{array}$ & $\begin{array}{c}\text { Implementation } \\
\text { stage }\end{array}$ & $\begin{array}{c}\text { Occupancy } \\
\text { type }\end{array}$ & $\begin{array}{c}\text { Buildings } \\
\text { height } \\
\text { System } \\
\text { level }\end{array}$ \\
\hline GPRS & $\bullet$ & & & - & & & $\bullet$ & & $\bullet$ & & \\
\hline LEED & $\bullet$ & & & - & • & & • & $\bullet$ & • & & \\
\hline CASBEE & & & $\bullet$ & $\bullet$ & & $\bullet$ & & & & & $\bullet$ \\
\hline BREEAM & & $\bullet$ & & $\bullet$ & $\bullet$ & & $\bullet$ & $\bullet$ & & $\bullet$ & \\
\hline ISB tool & & & $\bullet$ & $\bullet$ & & - & & & & $\bullet$ & \\
\hline
\end{tabular}

Source: the author

\section{Overview of The Credits categories of (GPRS)}

The method of assessment is implemented numerically with assessment methodology achieved through criteria system with a design checklist of mandatory prerequisites and optional credits. The process is done by point-scoring credits to determine the certification level of the project. The GBRSs certificates are classified to platinum, gold, silver and certified.

Any project must satisfy all the compulsory minimum requirements and must obtain credit points by achieving assured criteria to obtain GPRS certification. These projects are rated based on accumulated credit points, according to: 1) GPRS Certified: 40-49 credits,2) Silver Pyramid: 50-59 credits, 3) Gold Pyramid: 60-79 credits, 4) Green Pyramid: 80 credits and above, 5) Projects with less than 40 credits will be classified as Uncertified (The Green Pyramid Rating System (GPRS), 2011). GPRS include seven categories which in turn include sub-categories. Green Pyramid Category Weightings are as follows: 1) Sustainable site, accessibility, ecology $(15 \%)$; 2) Energy efficiency (25\%); 3) Water efficiency (30\%); 4) Materials and resources (10\%); 5) Indoor environmental quality (10\%); 6) Management (10\%); 7) Innovation and added value (bonus) (Ammar, 2012).

\section{Case Study Analysis Methodology}

Egypt is divided into seven regional units (see fig.2.), each region includes a number of governorates that are connected geographically and economically. When the Green Pyramid Rating System (GPRS) was proposed, and the weightings of the categories were put, it was not taken into account the wide variation in the potential and challenges of each region. Therefore, the study focused on highlighting this difference, and then it focused on Sinai region, which is part of the Suez Canal regional unit by analyzing the experience of activating The Green Pyramid Rating System (GPRS) during a competition held for this purpose. Therefore, the Case study analysis methodology is divided into:

Phase 1: Classification different zones of Egypt according to categories of (GPRS).

Phase 2: The brief of Green Worship House Competition. The focus is on the study area, Sinai

Phase 3: Proposals to develop The Green Pyramid Rating System (GPRS) based on the experience of participation in the competition

Figure 3. illustrates the conceptualization of the methodology by highlighting the relationship between The Categories of Green Pyramid Rating System (GPRS) and the regional units of Egypt. Moreover, it focuses on the Sinai Peninsula which is part of the Suez Canal region. 


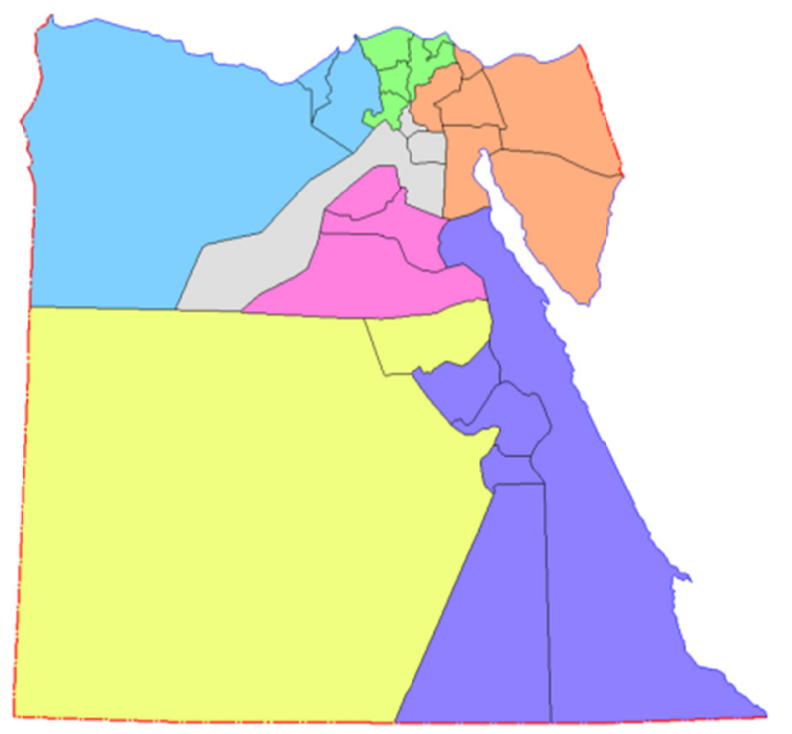

Map of Egypt's regional units for physical planning purposes.

] Greater Cairo Regional Unit

[ Alexandria Regional Unit

[Delta Regional Unit

[ Suez Canal Regional Unit

] North Upper Egypt Regional Unit

[] Asyut Regional Unit

[] South Upper Egypt Regional Unit

Figure 2. Map of Egypt's regional units

Source: Regional units of Egypt, (2015)

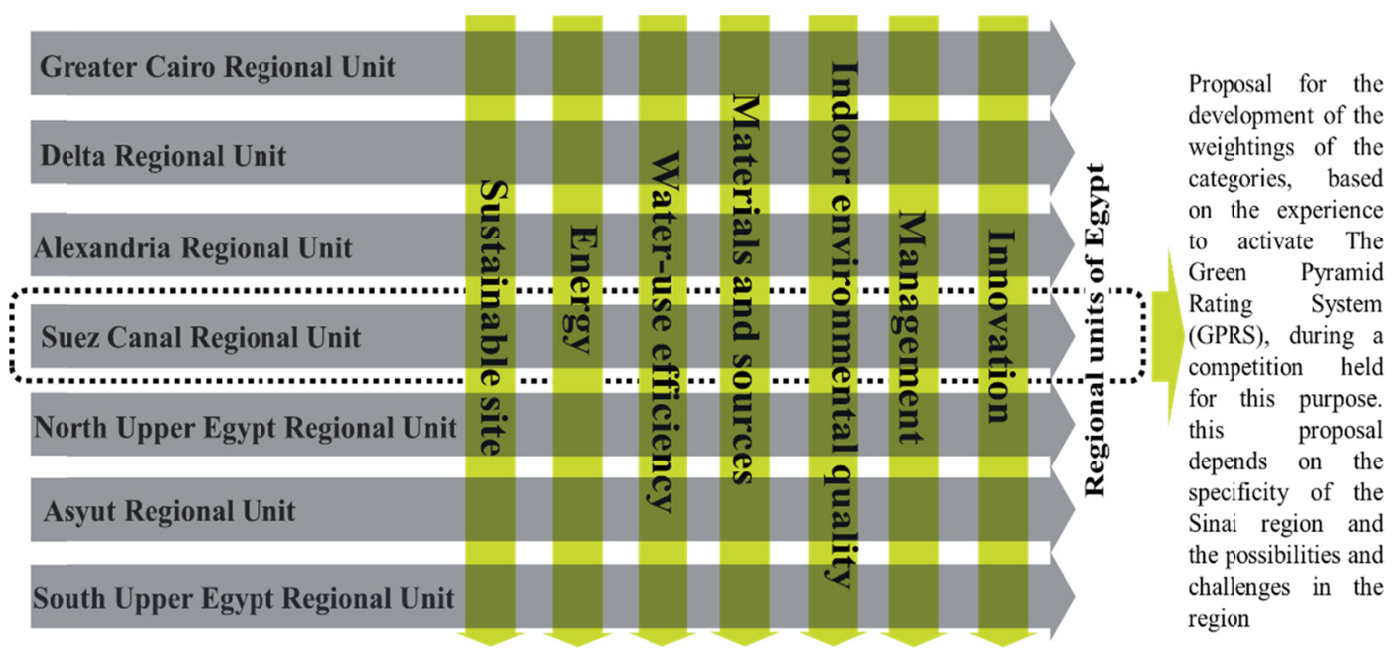

The Green Pyramid Rating System (GPRS) Categories

Figure 3. Conceptualization of the case study methodology

Source: the author

\section{Classification of Different Zones of Egypt According to Categories of (GPRS)}

The Arab Republic of Egypt is located in the north-eastern corner of Africa, Egypt is located between $22^{\circ} \mathrm{N}$ to $31^{\circ} 37^{\prime} \mathrm{N}$ latitude and $24^{\circ} 57^{\prime} \mathrm{E}$ to $35^{\circ} 45^{\prime} \mathrm{E}$ longitude, the total area of Egypt reaches nearly $1.002 .000 \mathrm{~m}^{2}$.

\subsection{Classification of Egypt Zones according to the Climate}

In terms of climate, Egypt has a great variation of climatic conditions; it is divided by the Egyptian Organization for Energy Conservation and Planning (EOECP) into seven different climatic design regions based on analyzing the climatic data observed at many meteorological stations. Those seven climatic design regions are: 1) the Mediterranean Sea Coastal Region, 2) the Red Sea Coastal Region, 3) the Semi- Moderate Region, 4) the Semi-Desert Region; 5) the Desert Region, 6) the Very Dry Desert Region and7) the Mountain Region. These regions vary greatly in the climatic conditions (Sayed, 2013). Another additional climate classification was developed by the Housing and Building Research Center (HBRC) in Egypt. This classification divided Egypt into eight climatic zones: 1) Northern Coast Zone, 2) Delta and Cairo Zone, 3) Northern Upper Egypt Zone, 4) 
Southern Upper Egypt Zone, 5) East Coast Zone, 6) Highlands Zone, 7) Desert Zone and8) Southern Egypt Zone. This classification depends on temperature, humidity, rainfall, wind speed, altitude and solar radiation, as well as the physical topography of the country. However, this study will use the HBRC Classification. Fig.4 shows the classification of the climatic zones in Egypt according to HBRC classification. As long as, the concept of green building involves the proper location of buildings, therefore, the study assumes that the classification of GPRS must take into consideration the great variation in the climate in different regions.

\subsection{Opportunities for Energy Availability in the Regions of Egypt}

The energy sector is a fundamental pillar of economic and social development. In addition to that, rationalization of non-renewable energies, good management and use, as well as relying on renewable energies are some of the most important development policies and strategies. Petroleum, natural gas and hydroelectricity are the main sources of energy for Egypt; however, Egypt is rich in many renewable energy sources. By analyzing the energy potential of renewable energy sources, it appears that Egypt, as one of the sun-belt countries, is endowed with high intensity direct solar radiation of $2000-3200 \mathrm{kWh} / \mathrm{m} 2 /$ year from north to south, as shown in Fig. 5. For the possibilities available for wind power generation, the areas of Gulf of Suez from south of Ain Sokhna to Hurghada are rich in resources of wind power, surpassing $10 \mathrm{~m} / \mathrm{s}$ (at a height of $25 \mathrm{~m}$ ). The regions along the coast of the Mediterranean Sea are some of the best suitable areas to employ both wind and solar energy, as shown in Wind and Solar Atlas of Egypt (Hanna, 2015; Khalil et al., 2010; Center, 2005), (see Fig. 6). As long as, the concept of green building involves promoting the optimal use of renewable energies, therefore, the study assumes that the classification of GPRS must take into consideration the apparent variation in the potential of each region in terms of the availability of renewable energy sources, and it gives more weight to the criterion of the exploitation of renewable energies in these areas to encourage designers to create designs based on renewable energies.

\subsection{Water-Use Efficiency}

In Egypt, water is the most essential natural resource. Lack and misuse of freshwater represent a major threat to living in Egypt. The management of water resources and the availability of water are the most important political and economic issues. Egypt is called "the gift of the Nile". Egypt also has long coastal areas on the Red Sea as well as the Mediterranean Sea. Life and the inhabited area are concentrated close to the water in the Nile Valley and the Delta. Groundwater is the second resource and is found in a number of aquifers (some are shallow while others are deep, some are renewable while others are non-renewable). Underneath the Nile Valley and Delta, oases are scattered in the Western Desert and the Sinai Peninsula. Moreover, there is another very important resource for water, which should be taken care of which is the desalinated seawater (Abou-Hadid, 2006), (see Fig. 7). As long as, the concept of green building involves promoting the management of water resources and the availability of new water resources, therefore, the study assumes that the classification of GPRS must take into consideration the apparent variation in the potential of each region in terms of availability of water resources, and it gives more weight to the criterion of the exploitation of water resources in those areas to encourage designers to create designs based on the optimal utilization of water resources.

\subsection{Population Density in Egypt}

Egypt is predominantly desert. Only $35,000 \mathrm{~km} 2-3.5 \%$ - of the total land area is cultivated. Egypt's geological history has produced four major physical regions: 1) Nile Valley and Nile Delta; 2) Western Desert, 3) Eastern Desert and 4) Sinai (see Fig. 8). Despite covering only about 5.5\% of the total area of Egypt, the Nile Valley and Nile Delta are the most important regions, being the country's only cultivable regions and supporting about $99 \%$ of the population. The desert environment areas in Egypt are 95\% of the total area of Egypt. The desert inhabitants live where there is water, plants as well as in the areas of mining. The desert environment exists in the three regions of Western Sahara and the Eastern Desert and the Sinai Peninsula (Geography of Egypt, 2019; David \& David, 2002), (see Fig. 9).

As long as, the concept of green building involves promoting the optimal selection of the project site and the optimal use of the possibilities and face challenges, therefore, the study assumes that the classification of GPRS must take into consideration the apparent variation in the potential and challenges of each regional unit in terms of population, potential and available resources, as well as the challenges facing each region, such as the challenges facing construction in desert areas that are away from the supply of resources and of energy, as well as the challenges facing construction in Sinai due to political problems. Therefore, the weight of the site category should be increased in the regions that have difficulty in implementing projects to encourage designers and decision-makers to choose sites away from population concentration. 


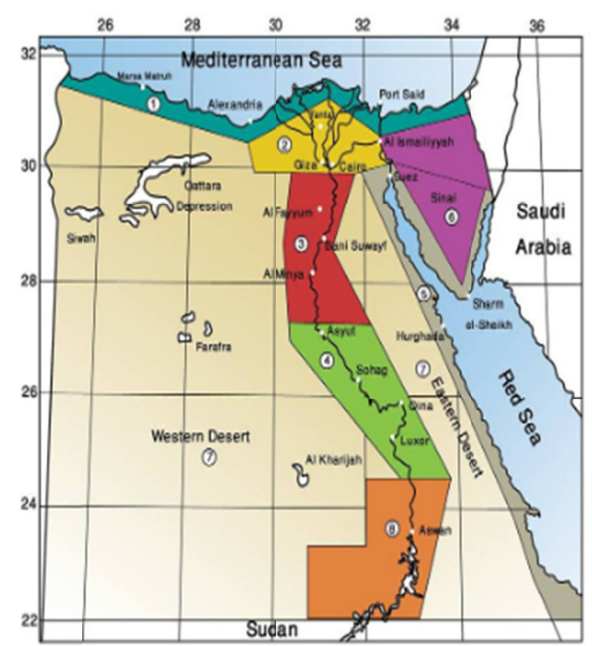

1. North Coast Region $\square$ 2-Delta and Cairo Region

$\square$ 4-Region ot Southern Upper Egypt $\square$ 5. East Coast Region

3-Aegion of Northerm Upper Egppt

$\square$ 7. Desent Region $\square$ 8. Region of Southern Egypt

Figure 4. Egypt's climatic zones classification map according to housing and building research center in Egypt

(HBRC)

Source: (Saleem et al., 2016).

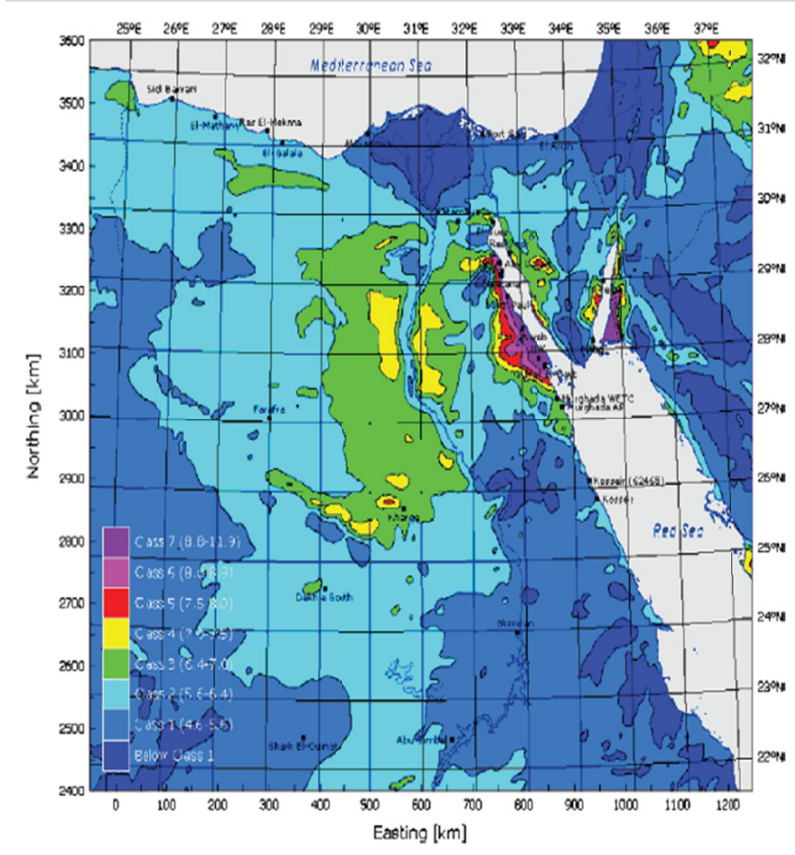

Figure 6. Wind regime map for Egypt (wind atlas for Egypt).

Source: (Khalil et al., 2010)

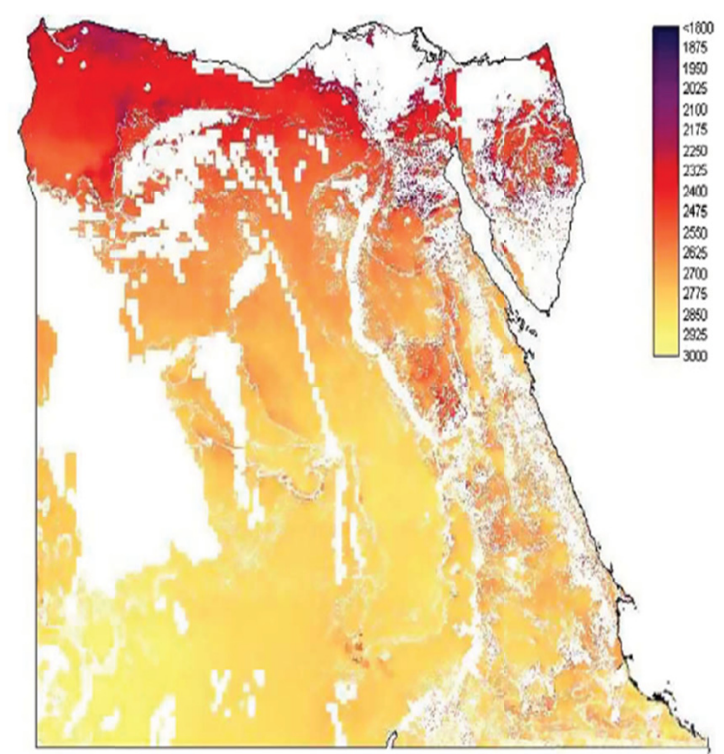

Figure 5. Solar radiation intensity map for Egypt (solar atlas for Egypt).

Source: (Khalil et al., 2010).

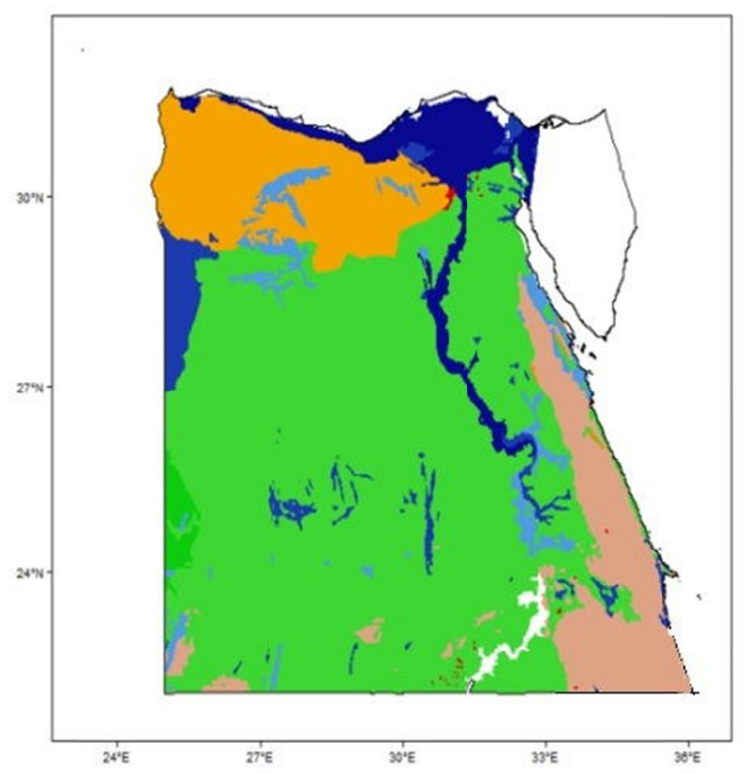

Figure 7. Hydrogeology map of Egypt.

Source: (Hydrogeology of Egypt, 2019). 


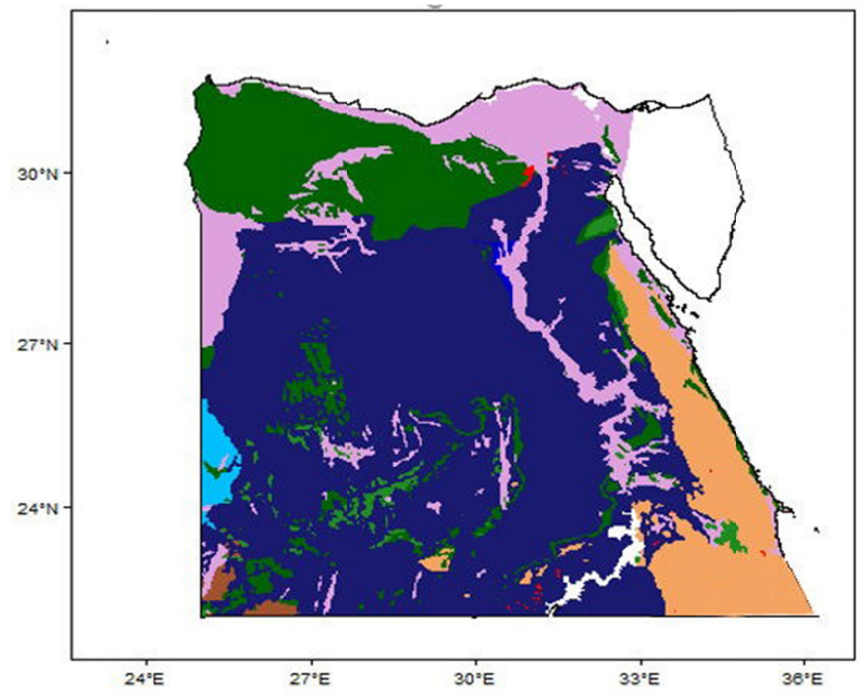

Figure 8. Geological Map of Egypt

Source: (Hydrogeology of Egypt, 2019).

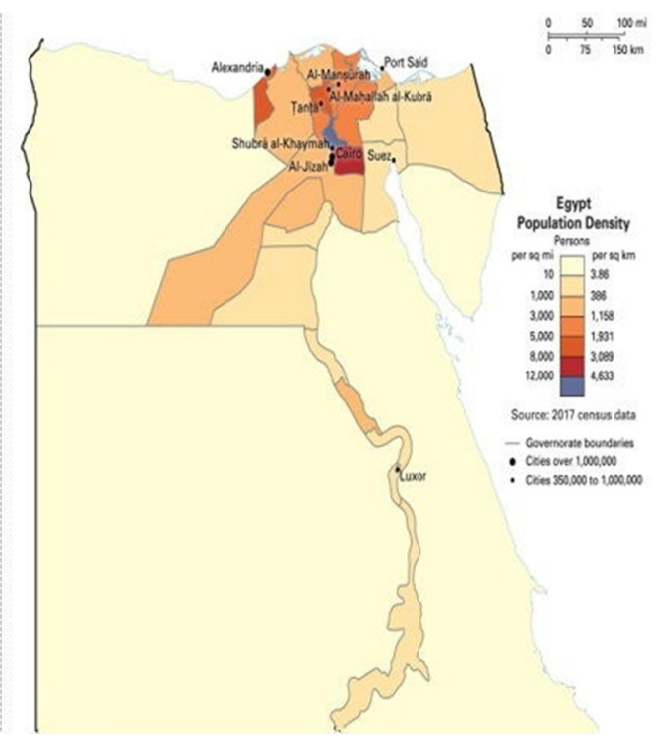

Figure 9. Map of Egypt's population density.

Source: (Encyclopedia Britannica, 2019)

According to the above analysis, it is clear that the differences between the regions of Egypt in terms of climate, the diversity of energy sources and resources, as well as the availability of clean water sources. Besides the great difference in the distribution of population densities in the regions, therefore, the study in the next part focuses on one of the regions of Egypt; Sinai, by analyzing the participation of one of the participants in a competition held for the purpose of developing the Green Pyramid.

\section{The Brief of Green Worship House Competition}

Green Worship House Competition aims at designing a Worship House that complies with all criteria of the Green Pyramid Rating System. This comes as a pilot initiative from The Housing and Building National Research Center (HBRC), Farouk El-Baz Centre for Sustainability and Future Studies (FECSFS) and The British University in Egypt (BUE) for expanding the application of the Green Pyramid Rating System (GPRS). Hence, applicants are required to investigate the assessment criteria stated by the Green Pyramids Rating System and apply it in their designs. The competition requires designing a worship house according to the rules mandated by the Green Pyramid Rating System. The proposed project should take into account all the standards of "Green Pyramid" during its life cycle process including design, construction, control, and management. This can be a mosque, church, or temple. This covers site selection, energy, water, materials, thermal comfort...etc., in addition to innovation and creativity.

The competition also proposed several sites to design places of worship, including: New Valley, New Cities, the New Administrative Capital, Suez Canal Region and Sinai and the Western Sahara by investigating the participants' designs, ideas and designs varied based on the chosen location of each group. As mentioned in the previous analysis, there is a very large difference between the regions in Egypt in terms of resources, energies, and population, as well as climatic and topographical factors. Accordingly, the study will present a summary of our participation in the competition in the following section, followed by an analysis of obstacles faced when applying the Green Pyramid criteria on the chosen site.

\subsection{Our Participation in Sinai}

Sinai is considered as one of the most influential strategic locations in Egypt. However, it suffers from the negligence of state institutions and the marginalization of Bedouins there. Moreover, Sinai faces multiple difficulties including the control of many armed groups in some areas, weak population, fragile services and feeble investments. The primary objective of this study is to design a mosque by the standards of the Green Pyramid as a symbol to commemorate the martyrs of Bir el Abd City. Furthermore, the study aims to design a mosque that acts as the nucleus of community gathering that affects the surrounding area and its residents positively. In addition, this design supports the development of the urban area and a model to be followed in all villages of the Peninsula of Sinai. In this context, the study deals with an analysis of the proposed site of the 
mosque. Subsequently, based on this analysis, the study identifies the approaches that could be employed to achieve all the standards of the Green Pyramid efficiently.

Firstly, the study succeeds in employing the demolition waste resulting from the attacks of the armed groups. Consequently, it suggests new and innovative construction systems based on the demolition waste of concrete bricks and pipes of all kinds. For more details, the diligent reader can refer to (Shahda \& Badawy, 2019). Secondly, the study proves the possibility of designing the mosque as a water supply station by absorbing moisture from the atmosphere. In addition, the study presents a system of managing the produced water with the support of the villagers so as to connect the residents socially and spiritually together. Thirdly, the study succeeds in attaining the highest rates of thermal and light comfort inside the mosque by utilizing numerous innovative environmental methods of treatment. Subsequently, the study is proved by applying environmental simulation programs where the highest rates and indicators of the environmental efficiency of the mosque have been attained. Fourthly, the study presents a system for operating the building by exploiting renewable energy via the use of photovoltaic cells and wind turbines. Subsequently, the study proves the success of using renewable energy systems by using environmental simulation programs. Fifthly, the study suggests strategies of construction with the support of the village residents. In addition, it presents a strategy of managing and operating the mosque building and facilities as well as strategies of reusing ablution water. Finally, the study suggests several innovative creations whether by inventing new construction methods, building water production plant, or designing the building with an innovative multidirectional block. Finally, the study has been accomplished by developing the proposed design that achieves the highest rates of all the standards of the Green Pyramid (see fig. 10).

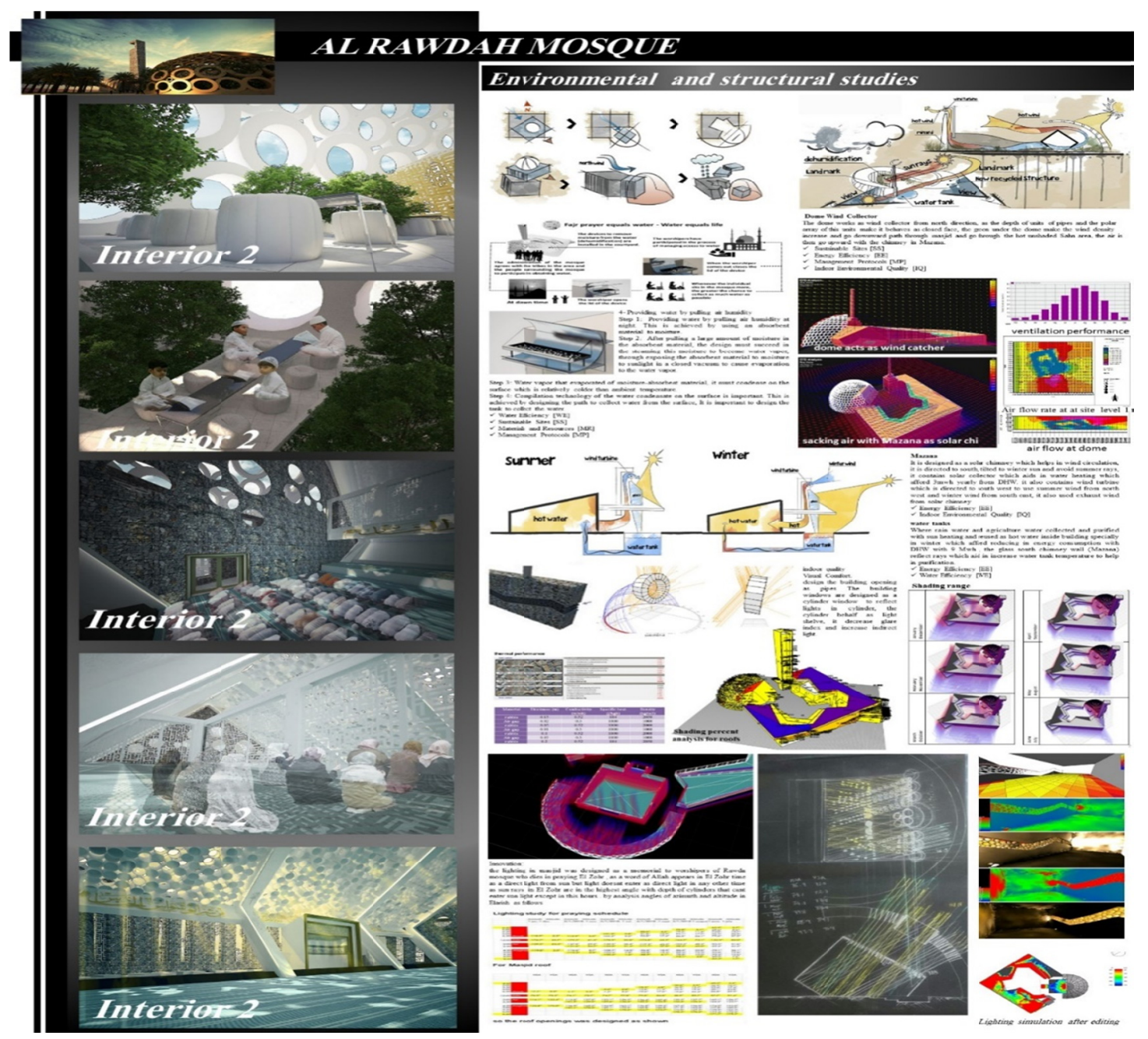

Figure 10. Part of the participation- Environmental and structural studies 


\section{Proposals to Develop the Green Pyramid Rating System (GPRS) Based on the Experience of Participation in the Competition}

Based on the previous analysis, which shows a clear difference in the climate, resources, and energies of each of the regions of Egypt as well as the previous presentation of the experience of participating in the Green Worship House Competition, in which the area of Sinai was chosen as the site of the proposed project, consequently, in this part the study presents a summary of what has been suggested during the participation to activate each category of Green Pyramid Rating System (GPRS), in addition to the observations and problems encountered in the design of the project and the activation of (GPRS) categories, then suggestions for developing the categories and weights of each category based on active participation in the Green Worship House Competition (see Table. 3).

Table 3. Proposals to develop The Green Pyramid Rating System (GPRS) in Sinai

\begin{tabular}{|c|c|c|c|}
\hline $\begin{array}{l}\text { The Green } \\
\text { Pyramid Rating } \\
\text { System (GPRS) } \\
\text { Categories }\end{array}$ & $\begin{array}{l}\text { Notes on the experience } \\
\text { of participation in the } \\
\text { activation (GPRS) }\end{array}$ & $\begin{array}{l}\text { Our participation to activate } \\
\text { (GPRS) } \\
\text { in Sinai }\end{array}$ & Suggestions for development \\
\hline Sustainable Site & $\begin{array}{l}\text { Sinai is far from the } \\
\text { concentration of the } \\
\text { population in the Nile } \\
\text { Valley and Delta, and has a } \\
\text { low population density }\end{array}$ & $\begin{array}{l}\text { The capabilities of the site and the } \\
\text { available materials are exploited. } \\
\text { Also, thesite analysis has the effect of } \\
\text { extracting an environmental concept } \\
\text { for the design }\end{array}$ & $\begin{array}{l}\text { Greater weights should be set for standards } \\
\text { that encourage and target the development of } \\
\text { remote areas such as Sinai }\end{array}$ \\
\hline Energy & $\begin{array}{l}\text { Sinai lacks electricity but } \\
\text { is rich in renewable } \\
\text { energies such as solar and } \\
\text { wind }\end{array}$ & $\begin{array}{l}\text { The design was based on the } \\
\text { exploitation of solar and wind energy, } \\
\text { by designing solar chimneys and } \\
\text { windcatchers. As well as the } \\
\text { generation of electrical energy from } \\
\text { solar cells }\end{array}$ & $\begin{array}{l}\text { Greater weights should be set for standards } \\
\text { that seek innovative solutions to exploit clean } \\
\text { renewable energies }\end{array}$ \\
\hline $\begin{array}{l}\text { Water-Use } \\
\text { Efficiency }\end{array}$ & $\begin{array}{l}\text { Sinai } \\
\text { groundwater, and is } \\
\text { surrounded by seawater } \\
\text { from all directions, but it } \\
\text { lacks clean water supplies }\end{array}$ & $\begin{array}{l}\text { The proposed design meets the water } \\
\text { needs of the project and the village, by } \\
\text { applying an innovation inspired by a } \\
\text { previous study (Shahda et al., 2018) to } \\
\text { draw moisture from the air and turn it } \\
\text { into drinking water }\end{array}$ & $\begin{array}{l}\text { The sub-points in this category should contain } \\
\text { larger weights for projects that create ways to } \\
\text { save water, including desalination }\end{array}$ \\
\hline $\begin{array}{l}\text { Materials } \\
\text { Sources }\end{array}$ & $\begin{array}{l}\text { Sinai is rich in resources } \\
\text { and materials and has a lot } \\
\text { of demolition waste }\end{array}$ & $\begin{array}{l}\text { The design relied on recycling } \\
\text { demolition waste to preserve the } \\
\text { ecosystem }\end{array}$ & $\begin{array}{l}\text { The weight of the sub-points that encourage } \\
\text { the idea of recycling should be greater }\end{array}$ \\
\hline $\begin{array}{l}\text { Indoor } \\
\text { Environmental } \\
\text { Quality }\end{array}$ & $\begin{array}{l}\text { The climate in Sinai varies } \\
\text { due to the diversity of } \\
\text { geography as well as the } \\
\text { distance and proximity to } \\
\text { the sea }\end{array}$ & $\begin{array}{l}\text { The design relied on environmental } \\
\text { treatments, for example, the } \\
\text { exploitation of solar and wind energy } \\
\text { to achieve thermal, glare and visual } \\
\text { comfort within the spaces }\end{array}$ & $\begin{array}{l}\text { There should be more sub-points to encourage } \\
\text { the design which is based on passive } \\
\text { environmental treatments }\end{array}$ \\
\hline Management & $\begin{array}{l}\text { Sinai is far from the central } \\
\text { administration and its } \\
\text { inhabitants } \\
\text { marginalized }\end{array}$ & $\begin{array}{l}\text { The design is based on the } \\
\text { management of the building process } \\
\text { with popular participation. Also, the } \\
\text { design proposes an idea to manage } \\
\text { access to water with the help of } \\
\text { residents }\end{array}$ & $\begin{array}{l}\text { The idea of popular participation in } \\
\text { construction in Sinai must be emphasized } \\
\text { because it is a goal in itself rather than a means } \\
\text { to develop a sense of belonging among } \\
\text { citizens. }\end{array}$ \\
\hline Innovation & $\begin{array}{l}\text { Sinai has many resources, } \\
\text { energies, great history and } \\
\text { wonderful geography that } \\
\text { can inspire designers to } \\
\text { innovate }\end{array}$ & $\begin{array}{l}\text { The design is based on many } \\
\text { innovations in lighting, water saving, } \\
\text { innovative environmental treatments } \\
\text { and new construction applications. }\end{array}$ & $\begin{array}{l}\text { The study suggests that the scores of the } \\
\text { innovation category can be divided into the six } \\
\text { previous categories because any innovation } \\
\text { will fall under the six basic categories, thus } \\
\text { concentrating innovations on the good } \\
\text { management and exploitation of resources and } \\
\text { energies }\end{array}$ \\
\hline
\end{tabular}

Source: the author 


\section{Conclusion}

- The development of GPRS is mainly based on assessment methodology; carried out by assigning point values to a selected number of parameters weighted, that differs from one zone to another, the fact that challenges GPRS to be adopted to all Egyptian zones. Integrated Design Process (IDP) could be used by regional third-party organizations to develop GPRS implementation on all Egyptian zones. GPRS uses D-tool (describe the 'strategies/process' of building practice (design, plan, management, etc.) where P-tool (describe the 'targets/results' of building activities and derive from building environmental science research and are typically more general and stable.) must be integrated to set locally relevant weights, benchmarks and standards established according to the potential functions (applicable areas) of the tools. According to the analysis of different weighted points of GPRS on the Egyptian zones, GPRS must be adapted, by using analytical methodology to score weighting and potential of implementing these points to design on each zone. Finally, splitting ratting assessment into three sections: design stage, construction stage and post-occupancy, as the first step in implementation of GPRS.

- Competitions are a good idea to try and activate any system under development, therefore countries should encourage such events for obtaining the views of participants and for employing those views in the development.

- Through analysis of the regions in Egypt, the great difference among regions in terms of climate, diversification of energy and resource resources, availability of clean water resources, and significant distribution of population densities in regions.

- Sinai has great geographical and historical characteristics. It also has many resources and renewable energies. However, Sinai is very sparsely populated. These sparse densities consist of Bedouin communities of very special character and culture. Sinai has few development projects, in addition to that there is a permanent feeling of marginalization from the state. So, all these particular characteristics of the region must be taken into account when designing projects.

- By analyzing the experience of participating in the Green Worship House Competition which was held for the purpose of activating the Green Pyramid, and with the selection of the Sinai region to be the proposed project site for our participation, the study offers some suggestions for the development of the Green Pyramid are :

- Greater weights should be set for standards that encourage and target the development of remote areas such as Sinai.

- Greater weights should be set for standards that seek innovative solutions to exploit clean renewable energies.

- The sub-points in this category should contain larger weights for projects that create ways to save water, including desalination.

- The weight of the sub-points that encourage the idea of recycling should be greater.

- There should be more sub-points to encourage.

- the design should be based on passive environmental treatments.

- The idea of popular participation in construction in Sinai must be emphasized because it is a goal in itself rather than a means to develop a sense of belonging among citizens.

- The study suggests that the scores of the innovation category can be divided into the six previous categories because any innovation will fall under the six basic categories, thus concentrating innovations in the good management and exploitation of resources and energies.

\section{Acknowledgments}

The authors would like to thank the reviewers for their insightful comments for the improvement of the manuscript.

\section{References}

Abou-Hadid, A. F. (2006). Water Use Efficiency in Egypt. AARINENA Water Use Efficiency Network, 38.

Aleem, S. H. A., Zobaa, A. F., \& Mageed, H. M. A. (2015). Assessment of energy credits for the enhancement of the Egyptian Green Pyramid Rating System. Energy Policy, 87, 407-416. https://doi.org/10.1016/j.enpol.2015.09.033 
Ali, H. H., \& Al Nsairat, S. F. (2009). Developing a green building assessment tool for developing countriesCase of Jordan. Building and Environment, 44(5), 1053-1064. https://doi.org/10.1016/j.buildenv.2008.07.015

Ammar, M. G. (2012). Evaluation of the Green Egyptian Pyramid. Alexandria Engineering Journal, 51(4), 293-304. https://doi.org/10.1016/j.aej.2012.09.002

Attia, S. (2014). The usability of green building rating systems in hot arid climates. ASHRAE Energy \& Indoor Environment for Hot Climates.

Attia, S., Hamdy, M., O'Brien, W., \& Carlucci, S. (2013). Assessing gaps and needs for integrating building performance optimization tools in net zero energy buildings design. Energy and Buildings, 60, 110-124. https://doi.org/10.1016/j.enbuild.2013.01.016

Ayyad, K. M., \& Gabr, M. (2012). Greening Building Codes in Egypt. Sustainable Futures: Architecture and Urbanism in the Global South Kampala, Uganda.

Bauer, M., Mösle, P., \& Schwarz, M. (2009). Green building: guidebook for sustainable architecture. Springer Science \& Business Media.

Bendewald, M., \& Zhai, Z. J. (2013). Using carrying capacity as a baseline for building sustainability assessment. Habitat International, 37, 22-32. https://doi.org/ 10.1016/j.habitatint.2011.12.021

BREEAM UK New Construction 2018 consultation, Technical Manual United Kingdom. Retrieved March, 2019, from https://tools.breeam.com/filelibrary/Consultations/SD5078_DRAFT-UK_nondom_NC_2018-manual. pdf

BREEAM UK New Construction non-domestic buildings technical manual 2014. Retrieved March, 2019, from https://www.breeam.com/BREEAMUK2014SchemeDocument/\#01_introduction_newcon/2introductiontobr eeam_nc.htm\%3FTocPath\%3DIntroduction\%2520to\%2520BREEAM\%7C

Cam, C. N., \& Ong, B. L. (2005, September). Building environmental assessment tools and the multidimensional pathways towards sustainable architecture. In Proceedings of the 2005 world sustainable building conference (SB05Tokyo) (pp. 27-29).

Center, G. A. (2005). Concentrating solar power for the Mediterranean region. German Aerospace Center (DLR) Institute of Technical Thermodynamics, Section Systems Analysis and Technology Assessment, Stuttgart.

Chen, X., Yang, H., \& Lu, L. (2015). A comprehensive review on passive design approaches in green building rating tools. Renewable and Sustainable Energy Reviews, 50, 1425-1436. https://doi.org/10.1016/j.rser.2015.06.003

Council, E. G. B. (2009). The GREEN PYRAMID rating system.

da Costa, M. J. R. C., Lages, J. P., da Costa, S. C., \& Roseta, F. (2017). Architectural Research Addressing Societal Challenges Volume 1: Proceedings of the EAAE ARCC 10th International Conference (EAAE ARCC 2016), 15-18 June 2016, Lisbon, Portugal. CRC Press.

David, A. R., \& David, R. (2002). The pyramid builders of ancient Egypt: a modern investigation of pharaoh's workforce. Routledge. https://doi.org/10.4324/9780203442616

Ding, G. K. (2014). Life cycle assessment (LCA) of sustainable building materials: an overview. In Eco-Efficient Construction and Building Materials (pp. 38-62). Woodhead Publishing. https://doi.org/10.1533/9780857097729.1.38

Doan, D. T., Ghaffarianhoseini, A., Naismith, N., Zhang, T., Ghaffarianhoseini, A., \& Tookey, J. (2017). A critical comparison of green building rating systems. Building and Environment, 123, 243-260. https://doi.org/10.1016/j.buildenv.2017.07.007

Elmeligy, D. A. (2014). Rating Systems Awareness for Green Buildings Applications. International Refereed Journal of Engineering and Science (IRJES).

Encyclopedia Britannica. (2019). Retrieved March, 2019, from https://www.britannica.com/place/Egypt/Demographic-trends

Geography of Egypt. (2019). Wikipedia, the free encyclopedia. Retrieved March, 2019, from http://en.wikipedia.org/wiki/Geography_of_Egypt

Gowri, K. (2004). Green building rating systems: An overview. ASHRAE journal, 46(11), 56. 
Green Pyramid Rating System (GPRS), 2011. The Egyptian Green Building Council, Housing and Building National Research Center.

Guilherme, P., \& Salema, S. (2017). Emerging research: The architect's personal research through design competitions. https://doi.org/10.1201/9781315226255-104

Haapio, A., \& Viitaniemi, P. (2008). A critical review of building environmental assessment tools. Environmental impact assessment review, 28(7), 469-482. https://doi.org/10.1016/j.eiar.2008.01.002

Hanna, G. B. (2015). Energy Efficiency Building Codes and Green Pyramid Rating System. In Renewable Energy in the Service of Mankind Vol I (pp. 597-608). Springer, Cham. https://doi.org/10.1007/978-3-319-17777-9_54

Holmes, S. (2018). What's new in LEED: LEED v4.1, U.S. Green Building Council. Retrieved March, 2019, from https://www.usgbc.org/articles/whats-new-leed-leed-v41

Hydrogeology of Egypt. (2019). British geological survey. Retrieved March, 2019, from http://earthwise.bgs.ac.uk/index.php/Hydrogeology_of_Egypt

Ismaeel, W. S. (2019). Drawing the operating mechanisms of green building rating systems. Journal of Cleaner Production, 213, 599-609. https://doi.org/10.1016/j.jclepro.2018.12.115

Khalil, A. K., Mubarak, A. M., \& Kaseb, S. A. (2010). Road map for renewable energy research and development in Egypt. Journal of Advanced Research, 1(1), 29-38. https://doi.org/10.1016/j.jare.2010.02.003

Khasreen, M., Banfill, P. F., \& Menzies, G. (2009). Life-cycle assessment and the environmental impact of buildings: a review. Sustainability, 1(3), 674-701. https://doi.org/10.3390/su1030674

Kubba, S. (2009). LEED practices, certification, and accreditation handbook. Butterworth-Heinemann.

Liu, Y., Prasad, D., Li, J., Fu, Y., \& Liu, J. (2005, September). A holistic approach to developing regionally specific framework for green building assessment tools in China. In Proceedings of the 2005 World Sustainable Building Conference (SB05 Tokyo), Tokyo, Japan (pp. 27-29).

Malmqvist, T., Glaumann, M., Assefa, G., Kindembe, B., Hult, H., Myhr, U., \& Eriksson, O. (2005). Environmental assessment of real estates-where natural and social sciences meet: the case of EcoEffect. In the International conference Sustainable Building 2005.

Mateus, R., \& Bragança, L. (2011). Sustainability assessment and rating of buildings: Developing the

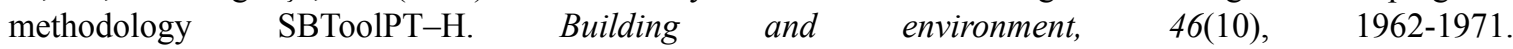
https://doi.org/10.1016/j.buildenv.2011.04.023.

Mattoni, B., Guattari, C., Evangelisti, L., Bisegna, F., Gori, P., \& Asdrubali, F. (2018). Critical review and methodological approach to evaluate the differences among international green building rating tools. Renewable and Sustainable Energy Reviews, 82, 950-960. https://doi.org/10.1016/j.rser.2017.09.105

Menteth, W., van't Klooster, I., Jansen, C., de Jager, M., Kristo, S., Isopp, A., ... Heilmeyer, F. (2017). Competition Culture in Europe: 2013-2016.

Murakami, S., Kawakubo, S., Asami, Y., Ikaga, T., Yamaguchi, N., \& Kaburagi, S. (2011). Development of a comprehensive city assessment tool: CASBEE-City. Building Research \& Information, 39(3), 195-210. https://doi.org/10.1080/09613218.2011.563920

Murakami, S., Kawakubo, S., Asami, Y., Ikaga, T., Yamaguchi, N., \& Kaburagi, S. (2010). Concept and Framework of CASBEE-City: An Assessment Tool of the Built Environment of Cities. In Proc. 2010 Conf. Sustainable Building.

Rana, A., \& Bhatt, R. (2016). Methodology for Developing Criteria weights for Green Building Rating Tool For Gujarat State.

Regional units of Egypt. (2015). Wikipedia. Retrieved March, 2019, from https://en.wikipedia.org/wiki/Regional_units_of_Egypt

Reich, M. C. (2005). Economic assessment of municipal waste management systems - case studies using a combination of life cycle assessment (LCA) and life cycle costing (LCC). Journal of Cleaner Production, 13(3), 253-263. https://doi.org/10.1016/j.jclepro.2004.02.015

Saleem, A. A., Abel-Rahman, A. K., Ali, A. H. H., \& Ookawara, S. (2016). An analysis of thermal comfort and energy consumption within public primary schools in Egypt. IAFOR J. Sustain. Energy Environ., 3. 
https://doi.org/10.22492/ijsee.3.1.03

Sayed, A., Hiroshi, Y., Goto, T., Enteria, N., Radwan, M. M., \& Eid, M. A. (2013). An Analysis of Thermal Comfort for Indoor Environment of the New Assiut Housing in Egypt. International Journal of Civil, Environmental, Structural, Construction and Architectural Engineering, 7(5), 204-210.

Shahda, M. M., \& Badawy, M. N. (2019). Recycling Concept Starts from the Design Stage: Five Architectural Applications based on the Reuse of Construction and Demolition Waste. International Journal of Science and Research (IJSR), 8(10).

Shahda, M. M., Elhafeez, M. M. A., \& El Mokadem, A. A. (2018). Camel's nose strategy: New innovative architectural application for desert buildings. Solar Energy, 176, 725-741. https://doi.org/10.1016/j.solener.2018.10.072

The Green Pyramid Rating System (GPRS). (2011). The Housing and Building National Research Center \& The Egyptian Green Building Council. Retrieved March, 2019, from $\mathrm{http} / / /$ www.eg.saint-gobainglass.com/download/file/fid./

Todd, J. A., Crawley, D., Geissler, S., \& Lindsey, G. (2001). Comparative assessment of environmental performance tools and the role of the Green Building Challenge. Building Research \& Information, 29(5), 324-335. https://doi.org/10.1080/09613210110064268

Wenzel, H., Hauschild, M. Z., \& Alting, L. (2000). Environmental Assessment of Products: Volume 1: Methodology, tools and case studies in product development (Vol. 1). Springer Science \& Business Media.

Zannoun, M. S. (2009). Egypt's renewable energy strategy, achievements and programs. New and Renewable Energy Authority, Egypt.

\section{Copyrights}

Copyright for this article is retained by the author(s), with first publication rights granted to the journal.

This is an open-access article distributed under the terms and conditions of the Creative Commons Attribution license (http://creativecommons.org/licenses/by/4.0/). 